\title{
The potential of endophytic bacteria isolated from Tagetes sp. to control Meloidogyne spp. infection on tomato plants
}

\author{
ABDUL MUNIF ${ }^{1, \boldsymbol{v}}$, MUHAMMAD NURSALIM ${ }^{1}$, ANKARDIANSYAH PANDU PRADANA ${ }^{2}$ \\ ${ }^{1}$ Department of Plant Protection, Faculty of Agriculture, Institut Pertanian Bogor. J1. Meranti, IPB Dramaga Campus, Bogor 16680, West Java, Indonesia. \\ Tel./fax.: +62-251-8629353, `email: abdulmunif@ipb.ac.id \\ ${ }^{2}$ Department of Plant Protection, Faculty of Agriculture, Universitas Jember. Jl. Kalimantan No. 37, Tegalboto Campus, Jember 68121, East Java, \\ Indonesia
}

Manuscript received: 17 March 2021. Revision accepted: 18 May 2021.

\begin{abstract}
Munif A, Nursalim M, Pradana AP. 2021. The potential of endophytic bacteria isolated from Tagetes sp. to control Meloidogyne spp. infection on tomato plants. Biodiversitas 22: 3229-3236. The root-knot nematode (Meloidogyne spp.) is one of the plant-parasitic nematodes that cause economical loss in the vegetable plantations in the world. The endophytic bacteria may act as a potential biological agent to control the plant-parasitic nematodes. The aim of this study was to explore the endophytic bacteria from Tagetes sp., which had a potential to control Meloidogyne spp. and act as growth promoter for tomato plants. The endophytic bacteria were isolated from the roots and stems of Tagetes sp. and tissues were cultured on the tryptic soy agar (TSA) media. The endophytic bacterial isolates were selected using hypersensitive and blood agar tests to identify their biological safety. The selected endophytic bacteria were also assessed for growth promoter test in the tomato plants. The selected endophytic bacteria were assessed in vitro against the Meloidogyne spp. juvenile 2 and their effectiveness in suppressing the root-knot nematodes on tomato plants in greenhouse. The results showed that total of 184 endophytic bacterial isolates were successfully isolated from the roots and stem of Tagetes sp. In hypersensitive and hemolytic tests, 78 and 36 isolates showed negative responses, respectively. Of the 36 isolates tested, it was found that 14 of them were able to promote the growth of tomato seedlings. In in vitro test, 14 endophytic bacteria showed 73-93\% mortality rate of Meloidogyne spp J2. The results at greenhouse showed that 3 bacterial isolates, namely, AL21, AL44, and AL53 suppress the number of root-knot nematodes up to 50-74\% and improve tomato plant growth by $32 \%$. These results indicate that endophytic bacteria isolated from Tagetes sp. have the potential to act as biocontrol agents of parasitic nematodes and a plant growth promoter.
\end{abstract}

Keywords: Biocontrol, Meloidogyne, mortality, secondary metabolites, Tagetes

\section{INTRODUCTION}

The root-knot nematode (Meloidogyne spp.) is one of the plant-parasitic nematodes causing economical loss in vegetable plantations in the world. The agricultural yield loss around the world due to plant-parasitic nematodes reached 100 billion US dollars (Elling 2013). The estimation of yield loss in tropical plants such as eggplants was $17 \%-20 \%$, melon $18 \%-33 \%$, and tomatoes $23 \%$ $38 \%$ (Luc et al. 2005). Ralmi et al. (2016) reported that worldwide yield loss due to root-knot nematodes on potato reached $15 \%$ and in vegetables, it was $50-80 \%$. Symptoms are difficult to diagnose due to the attack of Meloidogyne spp. on the soil surface and plants usually show stunted growth, yellowing, and wilting in less water conditions (Subedi et al. 2020). These damages will commonly inhibit the water and nutrient absorptions, and translocation. The secondary infection by other pathogens causes rotting symptom spread from the nematode infection (Singh et al. 2019).

Nematode control can be attempted using chemical nematicides, resistant variety, land sanitation, liming in the infested land, plant rotation, uprooting the infested plant, and by biological control (Ralmi et al. 2016). The nematode control found often uses chemical materials. The excessive use of chemical materials creates a new environment for the plant pathogens, due to which they become resistant (Ntalli and Caboni 2012). Furthermore, the chemical materials can interfere with the beneficial microbes and human health (Kalliora et al. 2018). The control strategy of nematode plant-parasitic is focused on environmental safety and sustainable methods (Ralmi et al. 2016)

One of the alternative controls used in agricultural practices is nematocidal antagonistic plants. One of the antagonistic plants used as the nematode controller is Tagetes sp (Marahatta et al. 2012; Hanawi 2016). Tagetes sp. usually used as an alternative crop in crop rotation systems. In addition, some parts of this plant can also be used as raw materials for green organic fertilizer (Stroze et al. 2019). The secondary metabolites found in Tagetes sp. are triterpenoids, steroids, alkaloids, carotenoids, skeleton carbons, thiophene derivatives, benzofuran derivatives, and others. Several compounds found in Tagetes act as herbal medicine, insecticide, and fungicide (Verma and Verma 2012; Xu et al. 2012; Shetty et al. 2015). The capability of Tagetes sp. in controlling the plant-parasitic nematodes is not only due to its secondary metabolites, but also due to the rhizospheric and endophytic microorganism roles (Podolich et al. 2015; Hanawi 2016). The latest Information related to the endophytic bacteria availability and roles in the Tagetes sp. is still limited. 
Endophytic bacteria are defined as bacteria that colonize in the healthy plant tissue without causing symptoms or damage signs in the host plants (Miliute et al. 2015; Kandel et al. 2017). The endophytic bacterial colony can be detected or isolated using a surface sterilization method proliferated on the agar media. Endophytic bacteria are active to colonize in the plant tissue without any specific organ and naturally associated with the plant life cycle (Frank et al. 2017). On the other hand, endophytic bacteria could suppress some important diseases of plants through in vitro testing by producing antibiotics and secondary metabolite compounds (Munif et al. 2019).

The application of endophytic bacteria as biocontrol agents has several advantages: endophytic bacteria live in the same niche as pathogens; also, endophytic bacteria can induce plant resistance through the induced systemic resistance (ISR) mechanism. (Santos et al. 2018). The endophytic bacteria which inhabit plant tissue can be protected from unbeneficial environmental factors. Furthermore, another advantage of endophytic bacteria is that endophytic bacteria are easily formulated on various organic materials that are easy to find and cheap (Pavithra et al. 2020). In the future, endophytic bacteria are potentially developed and utilized as a biological agent (Munif et al. 2019). The aim of this study was to isolate endophytic bacteria from the Tagetes sp. and to observe their effect in controlling Meloidogyne spp.

\section{MATERIALS AND METHODS}

\section{Endophytic bacterial source plant}

The plant used in this study was Tagetes sp. collected from Dramaga Sub-district (Bogor, Indonesia) and Cipanas Sub-district (Cianjur, Indonesia). The selected plants were free from pests and diseases. The plant parts used as the source of endophytic bacteria were roots and stems.

\section{Isolation of endophytic bacteria}

Isolation of endophytic bacteria was carried out following the method described by Munif et al. (2019). The roots and stems of Tagetes sp. were washed under running water until cleaned, and then cut into several pieces $1-2$ $\mathrm{cm}$ in size. The root and stem pieces were sterilized using $70 \%$ alcohol for 1 minute and $2 \%$ sodium hypochlorite $(\mathrm{NaOCl})+$ Tween 20 for 3 minutes, and rinsed with sterile water thrice. The samples were air-dried with sterile tissue and placed in $20 \%$ tryptic soy agar (TSA) media to confirm successful surface sterilization. The root surface was confirmed sterile if within 48 hours there were no bacterial colonies on the TSA medium. If the surface sterilization fails, marked by the appearance of bacterial colonies, then the entire isolation process is repeated from the beginning.

The sterilized plant parts were crushed with mortar and pestle in laminar airflow. The crushed parts were diluted with sterile water at 4 times $\left(10^{-1}, 10^{-2}, 10^{-3}, 10^{-4}\right)$. The 0.1 $\mathrm{ml}$ suspension was dispersed on $20 \%$ TSA media and incubated at room temperature for 48 hours. The bacteria were purified with a sterile toothpick by streaking on $100 \%$ TSA media and incubated at room temperature for 48 hours. The bacteria were placed using Ose needle into the $100 \%$ TSB $+40 \%$ glycerol and kept at $-4{ }^{\circ} \mathrm{C}$.

\section{Hypersensitive test}

The hypersensitive test was performed to identify the pathogenicity of endophytic bacteria. The endophytic bacterial isolates were proliferated in $100 \%$ tryptic soy broth (TSB) media and incubated for 48 hours. The bacterial suspension was injected through an injection in the lower part of tobacco leaf at different internodes for each bacterial suspension. The tobacco plant was incubated for 48 hours. The symptoms were recorded $24-48$ hours after bacterial suspension injected. Plants that exhibited symptoms of necrosis were not used for the next test (Klement and Goodman 1967).

\section{Hemolytic activity test}

The endophytic bacterial isolates which showed negative reactions in the hypersensitive, were tested for their potential in hydrolyzing the mammal red blood cells. The hemolytic activity test follows the method as described by Vallet-Gely et al. (2010). The bacteria were grown on blood agar media and incubated for 24 hours and observed hemolytic zone formation. The hemolytic zone with a clear zone and a clear limit around the colony was called alphahemolysis; while the fairly dark zone formed around the colony (the alteration of media color to fairly dark green) was called beta-hemolysis. The endophytic bacteria which showed both hemolytic activities were not used for the next test due to danger for mammals, whereas endophytic bacteria that did not have clear or fairly dark zones around the colony was used for the next test.

\section{Potential test of endophytic bacteria as plant growth promoter}

The healthy and eligible tomato seeds were used for this test. These tomato seeds were soaked in 48-hour bacterial suspension for 30 minutes, and then grown in sterile media. The soil was moistened with water so that the seeds could germinate well. The percentage of tomato seed growth was recorded four weeks after planting (Munif et al. 2019). The best isolates were used for the next test.

\section{In vitro test against Meloidogyne spp. Juvenile 2}

The test was performed to identify the antibiotic activity of endophytic bacteria against Meloidogyne spp. juvenile 2. The in vitro test followed the method of Wiratno et al. (2019). The bacteria were grown on $100 \%$ TSA media for 48 hours at room temperature and harvested by exuviating them with $15 \mathrm{ml}$ sterile water. The bacterial suspension was centrifuged at $6500 \mathrm{rpm}$ for 15 minutes. The $4 \mathrm{ml}$ supernatant was transferred to counting dish filled with \pm 60 nematodes. The test was performed in 3 replications. The observation was performed at 6 hours, 10 hours, and 24 hours after treatment by notifying the number of nematode mortality. 


\section{Proteolytic activity test}

Skim milk agar (SMA) medium was used to test proteolytic activity. The SMA composed of $30 \mathrm{~g}$ TSB media, $15 \mathrm{~g}$ bacto agar, and $900 \mathrm{ml}$ distilled water was sterilized in an autoclave at $121^{\circ} \mathrm{C}$ temperature and $15 \mathrm{psi}$ (2 atm) pressure for 20 minutes. The media was cooled at $40^{\circ} \mathrm{C}-50^{\circ} \mathrm{C}$, and then milk was added into it $(10 \mathrm{~g}$ skim milk in $100 \mathrm{ml}$ distilled water) and sterilized at $110^{\circ} \mathrm{C}$ for 10 minutes. The SMA media was poured on Petri dish. The pure cultures of bacterial isolates were made by streaking method on SMA media and then incubated at room temperature for $48-72$ hours. The proteolytic activity was shown by the clear zone formation around the bacterial colony (Príncipe et al. 2007).

\section{Chitinolytic activity test}

The medium used was $1 \%$ chitin media, composed of $15 \mathrm{~g}$ bacto agar, $5 \mathrm{~g}$ glucose, $2 \mathrm{~g}$ peptone, $10 \mathrm{~g}$ chitin colloid, $0.5 \mathrm{~g} \mathrm{~K}_{2} \mathrm{HPO}_{4}, 0.5 \mathrm{~g} \mathrm{MgSO} 4,0.5 \mathrm{~g} \mathrm{NaCl}$ in $1 \mathrm{~L}$ distilled water. The media were sterilized using an autoclave at $121^{\circ} \mathrm{C}$ temperature and $15 \mathrm{psi}(2 \mathrm{~atm})$ pressure for 20 minutes. Endophytic bacteria were grown on chitin media by streaking method and incubated at room temperature for $48-72$ hours. The chitinolytic activity was marked by the formation of clear zone around the endophytic bacterial isolate after 3 days of incubation (Hariprasad et al. 2011).

\section{Influence of endophytic bacteria on Meloidogyne spp. in greenhouse}

This test was performed to identify the effect of endophytic bacterial against the Meloidogyne spp. infection on tomato plant growth. The tomato plants used in this study were Palupi cultivar tomato plants known to be susceptible to Meloidogyne spp. The endophytic bacterial treatments were performed by soaking the seeds into the endophytic bacterial suspension for 30 minutes. This experiment was performed with 4 treatments using three isolates, namely, AL21, AL44, and AL53, and a combination of these three isolates. Each treatment in this study was repeated 5 times. Each polybag of $15 \mathrm{~cm}$ x 20 $\mathrm{cm}$ size contained soil media and manure at 1:1 ratio $(\mathrm{v} / \mathrm{v})$, and was planted with one tomato plant. A suspension of 20 $\mathrm{ml}$ of bacteria was inoculated around the roots of the tomato plant. After seven days, plants were inoculated with \pm 1000 Meloidogyne spp. juvenile 2 nematodes per poly bag. The observation was made 3 weeks after inoculation, and then calculated the number of knots formed and measured the plant height, wet weight, and dry weight in each treatment replication (Munif et al. 2019).

\section{Data analysis}

The experiment was performed in completely randomized design. The average observation data results were analyzed using analysis of variance (ANOVA) at 5\% level with SPSS (16.0 version). If they are significantly different then Duncan Multiple Range Test (DMRT) at 95\% level confidence was applied

\section{RESULTS AND DISCUSSION}

\section{Endophytic bacterial isolates}

The 184 endophytic bacterial isolates were successfully isolated from the roots and stems of Tagetes sp. collected from Cipanas (Cianjur) and Dramaga (Bogor). The endophytic bacterial population from each root sample was around $2.5 \times 10^{5}-2.0 \times 10^{6} \mathrm{cfu} \mathrm{g}^{-1}$ root, while from stem sample it was around $1.0 \times 10^{5}-1.5 \times 10^{5} \mathrm{cfu} \mathrm{g}^{-1} \mathrm{stem}$.

\section{Hypersensitive test}

The hypersensitive test results revealed that 78 (42.39\%) isolates of endophytic bacteria showed a negative reaction. The negative reaction was marked by the inexistence of necrosis in the tobacco leaf after inoculated with the endophytic bacterial suspension. The other 106 $(57.61 \%)$ bacterial isolates showed a positive reaction marked by the existence of necrosis. The endophytic bacterial isolates that showed a negative reaction had nonpathogenic characteristics and can be used as a biological agent to control plant disease (Table 1).

\section{Hemolytic activity test}

Based on the results of the hemolytic test, 27 (34.61\%) and $15(19.23 \%)$ endophytic bacterial isolates showed positive responses to $\alpha$-hemolysis and $\beta$-hemolysis, respectively, while the remaining 36 isolates did not show any hemolytic reactions. The positive hemolytic reaction was marked by the existence of clear and dark zones around the bacterial colonies. Of the 36 negative bacterial isolates, 10 isolates were obtained from stems and 26 isolates from roots (Table 1). These isolates were used for the next test and may serve as a potential biological agent.

\section{Potential of endophytic bacteria as plant growth promoter}

The bacterial isolates encoded with AL were originated from the roots and BL were originated from the stems in Dramaga Sub-district. While the AC isolates codes were isolated from roots and $\mathrm{BC}$ were isolated from the stems in Cipanas Sub-district. The results of germination capability, plant height, and fresh weight of tomato plants showed that all bacterial isolates promote plant growth (Table 2). Seeds soaked seed with AL21, AL44, and AL53 isolates showed the best plant height and fresh weight compared to the control treatment and other isolate treatments. Moreover, the germination capacity of AL21 and AL44 isolates were $100 \%$ and $90 \%$ in the first experiment, while in the second experiment AL53 isolate showed similar results to the control. The bacterial isolates that exhibit better plant growth than control were used for the next test.

\section{Potential of endophytic bacteria as bio nematicides}

Results of in vitro test showed that 24 hours after treatment (HAT) all bacterial isolates suppressed the nematode population number by $76.67-100 \%$. Table 3 presents the mortality percentage of Meloidogyne spp. J2 which was significantly different from control. The AC57, BL12, BL40, and BL51 isolates showed the highest mortality rate, although those isolates had insignificant differences among others. The AL27, AC61, and BC52 isolates showed a significant difference with the control and other isolates. 
Table 1. The hypersensitive reaction and hemolytic activity test of endophytic bacterial isolates from the Tagetes sp.

\begin{tabular}{|c|c|c|c|c|}
\hline $\begin{array}{l}\text { Isolate } \\
\text { code }\end{array}$ & Origin & $\begin{array}{l}\text { Plant } \\
\text { tissue }\end{array}$ & $\begin{array}{c}\text { Hypersensitive } \\
\text { test }\end{array}$ & $\begin{array}{c}\text { Hemolytic } \\
\text { test }\end{array}$ \\
\hline BL12 & Bogor & Stem & - & - \\
\hline BL26 & Bogor & Stem & - & - \\
\hline BL30 & Bogor & Stem & - & - \\
\hline BL40 & Bogor & Stem & - & - \\
\hline BL51 & Bogor & Stem & - & - \\
\hline $\mathrm{BC} 47$ & Cianjur & Stem & - & - \\
\hline BC48 & Cianjur & Stem & - & - \\
\hline BC51 & Cianjur & Stem & - & - \\
\hline BC52 & Cianjur & Stem & - & - \\
\hline BC59 & Cianjur & Stem & - & - \\
\hline AL04 & Bogor & Root & - & - \\
\hline AL06 & Bogor & Root & - & - \\
\hline AL15 & Bogor & Root & - & - \\
\hline AL18 & Bogor & Root & - & - \\
\hline AL21 & Bogor & Root & - & - \\
\hline AL26 & Bogor & Root & - & - \\
\hline AL27 & Bogor & Root & - & - \\
\hline AL29 & Bogor & Root & - & - \\
\hline AL30 & Bogor & Root & - & - \\
\hline AL36 & Bogor & Root & - & - \\
\hline AL44 & Bogor & Root & - & - \\
\hline AL53 & Bogor & Root & - & - \\
\hline $\mathrm{ACO} 2$ & Cianjur & Root & - & - \\
\hline $\mathrm{AC} 04$ & Cianjur & Root & - & - \\
\hline $\mathrm{AC} 05$ & Cianjur & Root & - & - \\
\hline $\mathrm{AC} 18$ & Cianjur & Root & - & - \\
\hline AC20 & Cianjur & Root & - & - \\
\hline AC26 & Cianjur & Root & - & - \\
\hline $\mathrm{AC} 27$ & Cianjur & Root & - & - \\
\hline AC39 & Cianjur & Root & - & - \\
\hline $\mathrm{AC} 42$ & Cianjur & Root & - & - \\
\hline $\mathrm{AC} 43$ & Cianjur & Root & - & - \\
\hline AC57 & Cianjur & Root & - & - \\
\hline AC59 & Cianjur & Root & - & - \\
\hline AC61 & Cianjur & Root & - & - \\
\hline AC62 & Cianjur & Root & - & - \\
\hline
\end{tabular}

\section{Physiological characteristics of endophytic bacteria}

Results showed that out of 14 bacterial isolates, 2 isolates namely, AL44 and AL53 were capable to degrade chitin and 5 isolates (AL44, AL53, AC04, BC52 and BL51) were able to degrade protein (Table 4).

Effectiveness of endophytic bacteria as biocontrol agent against Meloidogyne spp. at greenhouse

Three endophytic bacterial isolates AL21, AL44, and AL53 used in greenhouse experiment against Meloidogyne spp. J2. Results showed that agronomy variables in plants with bacterial isolate treatments were better than the plants without bacterial treatment (control). The combination of endophytic bacteria showed better results in terms of plant height compared to single endophytic bacterial application. Plants treated with combined endophytic bacteria could promote the plant height by $32 \%$, while plants treated with single endophytic bacteria treatments were capable to promote plant height up to $23 \%$ (Table 5). Tomato plants without endophytic bacterial application had higher number of knots than the tomato plants with endophytic bacterial application (Figure 1).
Table 2. The influence of endophytic bacteria in germination capability, plant height, and wet weight of 4 -week tomato plants

\begin{tabular}{|c|c|c|c|}
\hline Isolate code & $\begin{array}{l}\text { Germination } \\
\text { capability }(\%)\end{array}$ & $\begin{array}{l}\text { Plant height } \\
(\mathrm{cm})^{\mathrm{a}}\end{array}$ & $\begin{array}{l}\text { Wet weight } \\
\text { (gram) }^{\mathrm{a}}\end{array}$ \\
\hline \multicolumn{4}{|c|}{ First experiment } \\
\hline Control & 90 & $9.20 \mathrm{bc}$ & $0.34 \mathrm{~cd}$ \\
\hline AL04 & 80 & $9.40 \mathrm{bc}$ & $0.36 \mathrm{~cd}$ \\
\hline AL06 & 100 & $9.33 \mathrm{bc}$ & $0.27 \mathrm{~d}$ \\
\hline AL18 & 90 & $10.06 \mathrm{bc}$ & $0.34 \mathrm{~cd}$ \\
\hline AL15 & 90 & $9.40 \mathrm{bc}$ & $0.34 \mathrm{~cd}$ \\
\hline AL26 & 100 & $9.16 \mathrm{bc}$ & $0.31 \mathrm{~d}$ \\
\hline AL27 & 100 & $10.73 \mathrm{~b}$ & $0.44 \mathrm{c}$ \\
\hline AL21 & 100 & $13.56 \mathrm{a}$ & $0.71 \mathrm{a}$ \\
\hline AL29 & 90 & $8.90 \mathrm{c}$ & $0.31 \mathrm{~d}$ \\
\hline AL36 & 80 & $9.53 \mathrm{bc}$ & $0.36 \mathrm{~cd}$ \\
\hline AL30 & 60 & $9.40 \mathrm{bc}$ & $0.35 \mathrm{~cd}$ \\
\hline AL44 & 90 & $12.40 \mathrm{a}$ & $0.58 \mathrm{~b}$ \\
\hline
\end{tabular}

Second experiment

Control $\quad 100-6.80 \mathrm{~b}$

$\begin{array}{llll}\text { AL53 } & 100 & 9.13 \mathrm{a} & 0.47 \mathrm{a}\end{array}$

$\begin{array}{llll}\mathrm{AC} 02 & 90 & 6.77 \mathrm{~b} & 0.27 \mathrm{~b}\end{array}$

$\begin{array}{llll}\mathrm{AC} 04 & 100 & 6.80 \mathrm{~b} & 0.29 \mathrm{~b}\end{array}$

$\begin{array}{llll}\mathrm{AC} 05 & 90 & 8.00 \mathrm{ab} & 0.28 \mathrm{~b}\end{array}$

$\begin{array}{llll}\mathrm{AC} 18 & 100 & 7.30 \mathrm{ab} & 0.27 \mathrm{~b}\end{array}$

$\begin{array}{llll}\text { AC20 } & 90 & 6.66 \mathrm{~b} & 0.31 \mathrm{~b}\end{array}$

$\begin{array}{llll}\text { AC26 } & 100 & 7.77 \mathrm{ab} & 0.31 \mathrm{~b}\end{array}$

$\begin{array}{llll}\text { AC27 } & 90 & 7.43 \mathrm{ab} & 0.26 \mathrm{~b}\end{array}$

$\begin{array}{llll}\text { AC39 } & 60 & 6.97 \mathrm{~b} & 0.31 \mathrm{~b}\end{array}$

$\begin{array}{llll}\text { AC42 } & 90 & 7.17 \mathrm{ab} & 0.34 \mathrm{ab}\end{array}$

$\begin{array}{llll}\text { AC43 } & 90 & 7.43 \mathrm{ab} & 0.25 \mathrm{~b}\end{array}$

Third experiment

\begin{tabular}{llll} 
Control & 80 & $6.40 \mathrm{c}$ & $0.23 \mathrm{~b}$ \\
AC57 & 90 & $7.53 \mathrm{abc}$ & $0.28 \mathrm{ab}$ \\
AC59 & 60 & $7.00 \mathrm{abc}$ & $0.23 \mathrm{~b}$ \\
AC61 & 100 & $8.20 \mathrm{a}$ & $0.28 \mathrm{ab}$ \\
AC62 & 90 & $6.60 \mathrm{bc}$ & $0.24 \mathrm{~b}$ \\
BC47 & 100 & $8.30 \mathrm{a}$ & $0.31 \mathrm{ab}$ \\
BC48 & 70 & $7.83 \mathrm{abc}$ & $0.27 \mathrm{ab}$ \\
BC51 & 80 & $7.17 \mathrm{abc}$ & $0.22 \mathrm{~b}$ \\
BC52 & 90 & $7.80 \mathrm{abc}$ & $0.27 \mathrm{ab}$ \\
BC59 & 100 & $6.90 \mathrm{abc}$ & $0.25 \mathrm{ab}$ \\
BL12 & 100 & $7.90 \mathrm{abc}$ & $0.35 \mathrm{a}$ \\
BL26 & 100 & $7.23 \mathrm{abc}$ & $0.28 \mathrm{ab}$ \\
BL30 & 100 & $7.57 \mathrm{abc}$ & $0.26 \mathrm{ab}$ \\
BL40 & 100 & $7.20 \mathrm{abc}$ & $0.29 \mathrm{ab}$ \\
BL51 & 80 & $8.10 \mathrm{ab}$ & $0.30 \mathrm{ab}$ \\
\hline
\end{tabular}

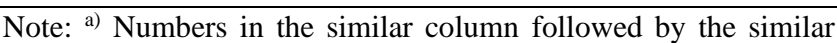
letter were insignificantly different at 0.05 confidence level (Duncan's multiple range test)

The seed soaking method and combined endophytic bacterial treatment were effective compared to the single endophytic bacterial treatment. In combined endophytic bacterial treatment, root-knots can be suppressed by $74.69 \%$, but the single endophytic bacterial treatment was able to suppress the number of knots by $63.37 \%$.

The results of root inoculation indicated that the scoring value of disease severity increased from 1 to 3 . The nematode inoculated tomato plants without the endophytic bacteria (control) showed 2 to 3 disease severity score, which was significantly different from endophytic bacteria 
and nematode treatments. Treatments with AL21, AL44, and AL53 isolates showed disease severity scores ranging from 1 to 2 , while the combined treatments of

Table 3. Effect of endophytic bacterial suspension on the mortality of Meloidogyne spp. juvenile 2

\begin{tabular}{lc}
\hline Bacterial isolate & Nematode mortality 24 HAT $^{\mathbf{a}}(\boldsymbol{\%})$ \\
\hline Control & $7.78 \mathrm{f}$ \\
AL21 & $93.88 \mathrm{abc}$ \\
AL27 & $76.67 \mathrm{e}$ \\
AL44 & $94.40 \mathrm{abc}$ \\
AL53 & $90.13 \mathrm{abcd}$ \\
AC04 & $88.38 \mathrm{bcd}$ \\
AC57 & $100.00 \mathrm{a}$ \\
AC61 & $82.31 \mathrm{de}$ \\
AC62 & $92.59 \mathrm{abcd}$ \\
BC47 & $98.30 \mathrm{ab}$ \\
BC52 & $85.92 \mathrm{~cd}$ \\
BL12 & $100.00 \mathrm{a}$ \\
BL30 & $96.99 \mathrm{ab}$ \\
BL40 & $99.16 \mathrm{a}$ \\
BL51 & $100.00 \mathrm{a}$ \\
\hline
\end{tabular}

Note: HAT: hours after supernatant treatment; $\left({ }^{\mathrm{a}}\right)$ numbers in the similar column followed by the similar letter were insignificantly different at 0.05 confidence level (Duncan's multiple range test).

Table 5. Influence of endophytic bacterial isolates in tomato plant growth

\begin{tabular}{llcl}
\hline Bacterial isolates & $\begin{array}{c}\text { Plant height } \\
(\mathbf{c m})^{\mathbf{a}}\end{array}$ & $\begin{array}{c}\text { Fresh } \\
\text { weight } \\
(\mathbf{g})^{\mathbf{a}}\end{array}$ & $\begin{array}{c}\text { Dry weight } \\
(\mathbf{g})^{\mathbf{a}}\end{array}$ \\
\hline Control & $46.30 \mathrm{~b}$ & $11.69 \mathrm{~b}$ & $1.51 \mathrm{c}$ \\
AL21 & $55.86 \mathrm{a}$ & $16.14 \mathrm{a}$ & $2.18 \mathrm{~b}$ \\
AL44 & $57.00 \mathrm{a}$ & $17.42 \mathrm{a}$ & $2.33 \mathrm{ab}$ \\
AL53 & $55.80 \mathrm{a}$ & $20.67 \mathrm{a}$ & $2.84 \mathrm{a}$ \\
AL21+AL44+AL53 & $61.16 \mathrm{a}$ & $19.29 \mathrm{a}$ & $2.69 \mathrm{ab}$ \\
\hline
\end{tabular}

Note: (a) numbers in the similar column followed by the similar letter was insignificantly different at 0.05 confidence level (Duncan's multiple range test).
AL21+AL44+AL53 showed lower disease severity i.e. 1. Moreover, the data about the number of root-knot data and scoring value are presented in Table 6 .

Table 4. Physiological characteristics of endophytic bacterial isolates from roots and stems of Tagetes sp.

\begin{tabular}{lcc}
\hline Isolate code & Proteolytic activity & Chitinolytic activity \\
\hline AL21 & - & - \\
AL27 & - & - \\
AL44 & + & - \\
AL53 & + & + \\
AC04 & + & + \\
AC57 & - & - \\
AC61 & - & - \\
AC62 & - & - \\
BC47 & - & - \\
BC52 & + & - \\
BL12 & - & - \\
BL30 & - & - \\
BL40 & - & - \\
BL51 & + & - \\
\hline Note: (+) capable of & producing enzymes; (-) incapable of \\
producing enzymes & &
\end{tabular}

Table 6. Influence of endophytic bacteria in the number of Meloidogyne spp. root-knot in tomato plant

\begin{tabular}{lccc}
\hline Isolate code & $\begin{array}{c}\text { Number of } \\
\text { knots per } \\
\text { gram root }^{\mathrm{a}}\end{array}$ & $\begin{array}{c}\text { Effectiveness } \\
\text { percentage } \\
(\boldsymbol{\%})\end{array}$ & $\begin{array}{c}\text { Scoring }^{\text {value }} \\
\text { valu }^{\mathrm{a}}\end{array}$ \\
\hline Control & $71.76 \mathrm{a}$ & 00.00 & $2.40 \mathrm{a}$ \\
AL21 & $28.28 \mathrm{~b}$ & 60.59 & $1.40 \mathrm{~b}$ \\
AL44 & $34.89 \mathrm{~b}$ & 51.37 & $1.40 \mathrm{~b}$ \\
AL53 & $26.28 \mathrm{~b}$ & 63.37 & $1.40 \mathrm{~b}$ \\
AL21+AL44+AL53 & $18.16 \mathrm{~b}$ & 74.69 & $1.0 \mathrm{~b}$ \\
\hline
\end{tabular}

Note: (a) numbers in the similar column followed by the similar letter was insignificantly different at 0.05 confidence level (Duncan's multiple range test).
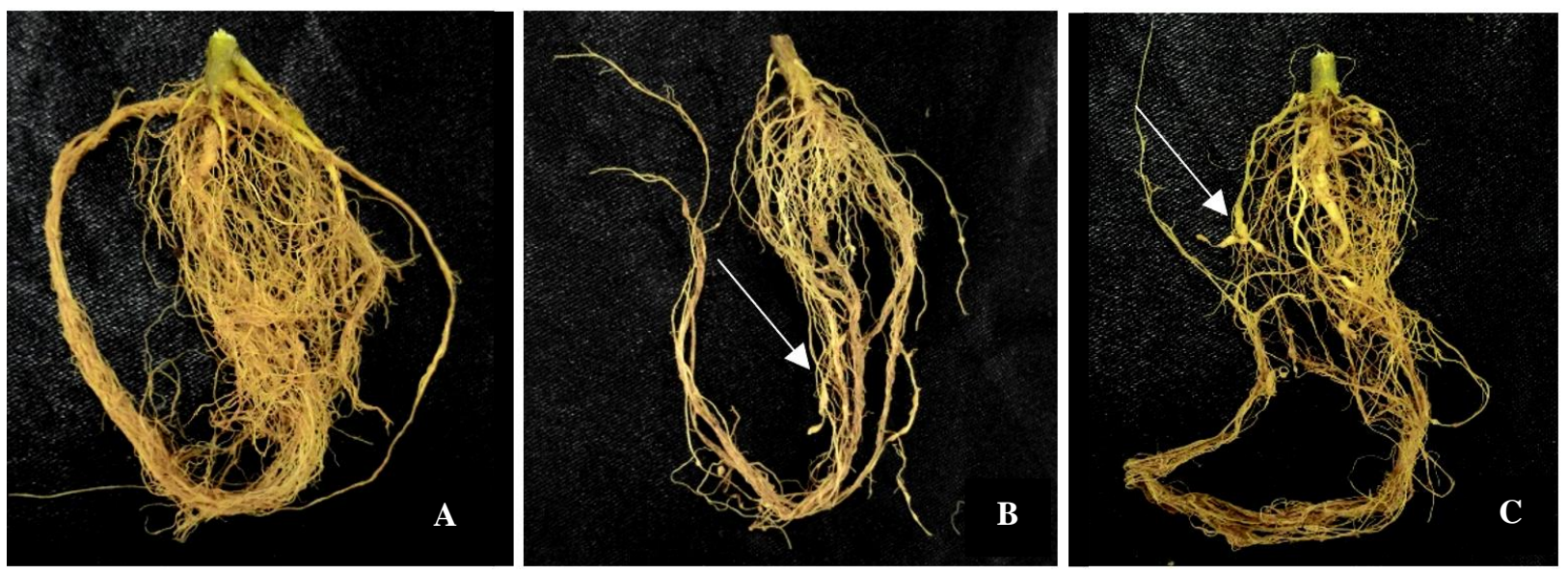

Figure 1. Tomato plant roots treated with: A. Combined bacteria of AL21+AL44+AL53; B. AL53; C. Control 


\section{Discussion}

The density of endophytic bacterial population in root was higher than in the stem. This condition was similar to the statement of Miliute et al. (2015), that the endophytic bacterial population in the root was higher than in the stem. The endophytic microbial population is influenced by biotic and abiotic factors. The biotic factors include plantassociated microbes, plant genotype, and plant age, while the abiotic factors include temperature, rainfall, edaphic factors, and UV radiation (Rosenblueth and MartínezRomero 2006; Chebotar et al. 2015; Firdous et al. 2019).

In the present study, several endophytic bacterial isolates showed hypersensitivity reactions. Hypersensitive is a host plant defense mechanism that develops quickly due to the unmatched pathogen with the host plant, which causes the dead cells (Klement and Goodman 1967; BalintKurti 2019). The dead cells caused by the hypersensitive occur only in infected tissue to protect the pathogen distribution in healthy plant tissue (Balint-Kurti 2019). Furthermore, the test results also showed that some isolates had hemolytic activity, indicated by the appearance of a clear zone on the test medium (blood agar). The clear zone was caused by $\alpha$-hemolysin toxin activity and the dark zone was caused by $\beta$-hemolysin toxin (Kumar et al. 2017). According to O'brien (2017), the biological agent is not only concerned with its effectiveness, but also the safety for human, animal, environmental health.

Endophytic bacteria obtained from hypersensitive and hemolytic activity selection tests were used for growth promoter tests. Some variables that are commonly used as growth characteristics are plant height, volume, leaf area, dry weight, and wet weight. The interaction between the endophytic bacteria and plant could promote plant growth and production, suppress pathogenic disease in plants, dissolve phosphate, fix nitrogen, and induce plant resistance against pathogens (Abdallah et al. 2016). Several strains of Pseudomonas, Enterobacter, Staphylococcus, Azotobacter, and Azospirillum could produce growth regulator compounds, namely, ethylene, auxin or cytokinin (Yadav et al. 2017; Mustafa et al. 2019). The endophytic bacteria could promote plant growth in two ways. First, in direct way by producing phytohormones, namely, auxin or cytokinin, or by producing 1-aminocyclopropanel-carbon (ACC) deaminase enzyme, which reduced ethylene level in plants (Win et al. 2018). Second, in indirect way by producing the plant nutrient, namely, nitrogen fixation, phosphate dilution, iron addition, and produce siderophores which can inhibit the absorption of nutrients by pathogens (Mardhiana et al. 2017; Ferreira et al. 2019; Munif et al. 2019).

Reports about the endophytic bacteria capability in nitrogen fixation, phosphate dilution, and phytohormone production have been much found. Endophytic bacteria have the ability to fix nitrogen in the root tissue of rice, corn, grass, sugarcane, and wheat (Stoltzfus et al. 1997; Sturz et al. 2000). According to Verma et al. (2001), Acetobacter diazotrophicus and Herbaspirillum spp. are two species of bacteria that can fix nitrogen in the rhizosphere of rice plants. Gupta et al. (2012) stated that the phosphate solubilizing bacteria (PSB) strain and endophytic bacteria, namely, Pseudomonas synxantha, Burkholderia gladiol, Enterobacter hormaechei, and Serratia marcescens, could increase the phosphate available in soil, absorb phosphate from soil, and increase the plant growth.

The endophytic bacteria from Enterobacter, Rahnella, Rhodanobacter, Pseudomonas, Stenotrophomonas, Xanthomonas, and Phyllobacterium genera were isolated from sweet potato (Ipomea batatas) could fix nitrogen, produce IAA hormone, and increase the plant resistance from less beneficial environment (Khan and Doty 2009). Moreover, the volatile compounds, namely, 2,3-butanediol and acetoin, were found in endophytic bacteria, which could promote plant growth (Taghavi et al. 2010). The endophytic bacteria were also reported to produce the adenine ribocides which became a plant growth promoter (Rosenblueth and Martínez-Romero 2006).

The in vitro test is needed to identify the secondary metabolite compounds produced from the endophytic bacteria in the Meloidogyne spp. juvenile 2 development. Total 14 bacterial isolates i.e. AL21, AL27, AL44, AL53, AC04, AC57, AC61, AC62, BC47, BC52, BL12, BL30, BL40, and BL51were used in the growth promoter potential test. According to Munif et al. (2019), the effect of endophytic bacterial filtrate culture on mortality of Meloidogyne spp. J2 showed that mortality occurred on 6 hours after treatment, and then increased 12 hours after treatment. The in vitro test showed that all bacterial isolates could inhibit Meloidogyne spp. J2 metabolism as marked by nematode mortality percentage.

According to Wiratno et al. (2019), nematode mortality was occurred due to its disrupted metabolism by the physiological activity of endophytic bacteria. The identified endophytic bacteria were capable of producing antibacterial or antifungal compounds through enzyme production, volatile compounds, lyser material, and other toxic substances (Chebotar et al. 2015; O'brien 2017; Pavithra et al. 2020). The endophytic bacteria that produce protease, chitinase, lipase, and cyanide acid, could control Meloidogyne incognita on tomato plant and Pratylenchus coffeae on coffee plant (Munif et al. 2019; Asyiah et al. 2020).

The external surface of contains flexible cuticle collagen, lipid enriched epicuticle, glycoprotein enriched surface-coat, and chitin (Johnstone 1994). Chitin, lipid, and protein are thought to degrade the chitinase, lipase, and protease enzyme activities. In addition to these three enzyme activities, the exposure of hydrogen cyanide (HCN) gas can be toxic to nematodes (Miliute et al. 2015; Ralmi et al. 2016; O’brien 2017).

Results of bacterial physiology tests revealed that several bacteria were capable of producing protease and chitinase enzymes. The endophytic bacterial proteolytic activity was shown by clear zone formation around the colony. This zone was formed due to the endophytic bacteria grew could produce protease enzyme, therefore capable of degrading the skim milk protein in the media. The proteolytic bacteria consume carbon sources in low 
concentration, and high protein content induces protease enzyme formation. The low carbon source may stimulate proteolytic bacteria to produce protease enzymes that degrade protein (Johnstone 1994).

Chitinase is an enzyme that catalyzes the chitin polymer compound in the $\beta-1,4$ glycosidic bond. This enzyme is produced by bacteria and other organisms, and has been used as a biological agent that degrades the pathogenic cell wall composed of chitin, namely, fungi and nematodes (Le and Yang 2019). The chitinolytic activity was marked by the formation of clear zone around the bacterial colony containing the chitin colloids. The Enterobacter sp. EAS (3a), Enterobacter ludwigii EAS (4), and Burkholderia cepacia EAS (6) were capable of producing protease, lipase, and chitinase enzymes. These bacteria were effective in vitro to inhibit the hatching rate at 53.13$81.92 \%$ and caused mortality of Meloidogyne spp. J2 at $81.4-95 \%$. The 2 of 14 isolates of the endophytic bacterial isolates could hydrolyze chitin (Afriyani et al. 2020).

In the greenhouse experiment, the seeds were soaked for 30 minutes and a suspension of bacteria was placed around the roots of the tomato plant. The seed soaking and endophytic bacterial pouring treatments were the methods to prevent plants from pathogen infection, including nematodes. One of the endophytic bacteria advantage for the host plant is induced systemic resistance (ISR) or through the systemic acquired resistance (SAR Bacteria affect the resistance genes and activate the signal transduction pathways in plants. This phenomenon involves jasmonic acid and ethylene compounds. Bacteria also produce certain compounds, namely lipopolysaccharides, which can induce plant resistance from biotic stress (Vallad and Goodman 2004; Pieterse et al. 2014). The plants treated with the endophytic bacteria could grow better than the untreated plants with endophytic bacteria, although these plants were infected with the rootknot nematodes (Munif et al. 2019).

Munif et al. (2019) mentioned that the application of combined antagonistic formulation could decrease the disease intensity compared to the single antagonistic formulation in low-tide land rice plants. The suppressive mechanism of root-knot formation by endophytic bacteria was thought due to the induction mechanism of plant resistance (Pieterse et al. 2014). Mika et al. (2010) stated that increased peroxidase and salicylic acid occurred as plant response against the elicitor materials produced by the endophytic bacteria, therefore the plants were capable of activating the resistance genes or providing the hypersensitive reaction against the nematode attack. In addition, endophytic bacteria are also reported to increase the thickness of the plant cell walls. Cell wall thickening in plants is reported to inhibit infection by pathogens (Anjum et al. 2019).

The result concludes that 184 endophytic bacterial isolates were successfully isolated from the Tagetes sp. Based on the hypersensitive and hemolytic tests, there were 14 bacterial isolates that did not show potential as pathogen either for plants or mammals. In in vitro test, these 14 isolates showed mortality percentage range of $70-93 \%$ in Meloidogyne spp. juvenile 2. The best three isolates, namely, AL21, AL44, and AL53 were capable to suppress the number of root knots by $50-74 \%$ and promote plant height up to $32 \%$ in the greenhouse experiment. So, the present investigation suggests that the endophytic bacteria consortium (combination) application was more effective than the single application.

\section{REFERENCES}

Abdallah RAB, Mokni-Tlili S, Nefzi A, Jabnoun-Khiareddine H, DaamiRemadi M. 2016. Biocontrol of Fusarium wilt and growth promotion of tomato plants using endophytic bacteria isolated from Nicotiana glauca organs. Biol Cont 97: 80-88. DOI: 10.1016/j.biocontrol.2016.03.005.

Anjum R, Afzal M, Baber R, Khan MAJ, Kanwal W, Sajid W, Raheel A. 2019. Endophytes: as potential biocontrol agent-review and future prospects. J Agric Sci 11: 113-125. DOI: 10.5539/jas.v11n4p113.

Arfiyani, Maulidia V, Sriwati R. 2020. Endophytic bacteria (Genus: Pseudomonas spp.) isolated from Aceh bamboo root as biological agent against nematode Meloidogyne spp. In: Sriwati R (eds) The 1st International Conference on Agriculture and Bioindustry. Aceh, Indonesia, 24-26 October 2019. DOI: 10.1088/17551315/425/1/012074.

Asyiah IN, Mudakir I, Hoesain M, Pradana AP, Djunaidy A, Sari RF. 2020. Consortium of endophytic bacteria and rhizobacteria effectively suppresses the population of Pratylenchus coffeae and promotes the growth of Robusta coffee. Biodiversitas 21 (10): 4702-4708.

Balint-Kurti P. 2019. The plant hypersensitive response: concepts, control and consequences. Mol Plant Pathol 20 (8): 1163-1178. DOI: 10.1111/mpp. 12821

Chebotar V, Malfanova N, Shcherbakov A, Ahtemova G, Borisov AY, Lugtenberg B, Tikhonovich I. 2015. Endophytic bacteria in microbial preparations that improve plant development. Appl Biochem Microbiol 51 (3): 271-277. DOI: 10.1134/S0003683815030059.

Elling AA. 2013. Major emerging problems with minor Meloidogyne species. Phytopathology 103 (11): 1092-1102. DOI: 10.1094/PHYTO-01-13-0019-RVW.

Ferreira MJ, Silva H, Cunha A. 2019. Siderophore-producing rhizobacteria as a promising tool for empowering plants to cope with iron limitation in saline soils: A review. Pedosphere 29 (4): 409-420. DOI: 10.1016/S1002-0160(19)60810-6.

Firdous J, Lathif NA, Mona R, Muhamad N. 2019. Endophytic bacteria and their potential application in agriculture: a review. Indian J Agric Res 53 (1): 1-7.

Frank AC, Saldierna Guzmán JP, Shay JE. 2017. Transmission of bacterial endophytes. Microorganisms 5 (4): 70. DOI: 10.3390/microorganisms5040070.

Gupta M, Kiran S, Gulati A, Singh B, Tewari R. 2012. Isolation and identification of phosphate solubilizing bacteria able to enhance the growth and aloin-A biosynthesis of Aloe barbadensis Miller. Microbiol Res 167 (6): 358-363. DOI: 10.1016/j.micres.2012.02.004.

Hanawi MJ. 2016. Tagetes erecta with native isolates of Paecilomyces lilacinus and Trichoderma hamatum in controlling root-knot nematode Meloidogyne javanica on tomato. Intl J Appl Innov Eng Manag 5 (1): 81-88.

Hariprasad P, Divakara S, Niranjana S. 2011. Isolation and characterization of chitinolytic rhizobacteria for the management of Fusarium wilt in tomato. Crop Prot 30 (12): 1606-1612. DOI: 10.1016/j.cropro.2011.02.032.

Johnstone IL. 1994. The cuticle of the nematode Caenorhabditis elegans: a complex collagen structure. Bioessays 16 (3): 171-178. DOI: 10.1002/bies.950160307.

Kalliora C, Mamoulakis C, Vasilopoulos E, Stamatiades GA, Kalafati L, Barouni R, Karakousi T, Abdollahi M, Tsatsakis A. 2018. Association of pesticide exposure with human congenital abnormalities. Toxicol Appl Pharmacol 346: 58-75. DOI: 10.1016/j.taap.2018.03.025.

Kandel SL, Joubert PM, Doty SL. 2017. Bacterial endophyte colonization and distribution within plants. Microorganisms 5 (4): 77. DOI: 10.3390/microorganisms5040077 
Khan Z, Doty SL. 2009. Characterization of bacterial endophytes of sweet potato plants. Plant Soil 322 (1): 197-207. DOI: 10.1007/s11104-0099908-1.

Klement Z, Goodman R. 1967. The hypersensitive reaction to infection by bacterial plant pathogens. Annu Rev Phytopathol 5 (1): 17-44. DOI: 10.1146/annurev.py.05.090167.000313.

Kumar V, Kumari A, Angmo K, Bhalla TC. 2017. Isolation and characterization of lactic acid bacteria from traditional pickles of Himachal Pradesh, India. J Food Sci Technol 54 (7): 1945-1952. DOI: $10.1007 / \mathrm{s} 13197-017-2629-1$.

Le B, Yang SH. 2019. Microbial chitinases: properties, current state and biotechnological applications. World J Microb Biotechnol 35 (9): 1 12. DOI: 10.1007/s11274-019-2721-y.

Luc M, Sikora RA, Bridge J. 2005. Plant Parasitic Nematodes in Subtropical and Tropical Agriculture. CABI, UK. DOI: 10.1079/9780851997278.0000.

Marahatta SP, Wang K-H, Sipes BS, Hooks CR. 2012. Effects of Tagetes patula on active and inactive stages of root-knot nematodes. J Nematol 44 (1): 26.

Mardhiana M, Pradana AP, Adiwena M, Santoso D, Wijaya R, Murtilaksono A. 2017. Use of endophytic bacteria from roots of Cyperus rotundus for biocontrol of Meloidogyne incognita. Biodiversitas 18 (4): 1308-1315. DOI: 10.13057/biodiv/d180404.

Mika A, Boenisch MJ, Hopff D, Lüthje S. 2010. Membrane-bound guaiacol peroxidases from maize (Zea mays L.) roots are regulated by methyl jasmonate, salicylic acid, and pathogen elicitors. J Exp Bot 61 (3): 831-841. DOI: 10.1093/jxb/erp353.

Miliute I, Buzaite O, Baniulis D, Stanys V. 2015. Bacterial endophytes in agricultural crops and their role in stress tolerance: a review. Zemdirbyste-Agriculture 102 (4): 465-478. DOI: $10.13080 / \mathrm{z}$ a.2015.102.060.

Munif A, Herliyana EN, Pradana AP. 2019. Endophytic bacterial consortium originated from forestry plant roots and their nematicidal activity against Meloidogyne incognita infestation in greenhouse. Acta Univ Agric et Silvic 67 (5): 1171-1182. DOI: 10.11118/actaun201967051171.

Mustafa S, Kabir S, Shabbir U, Batool R. 2019. Plant growth-promoting rhizobacteria in sustainable agriculture: from theoretical to pragmatic approach. Symbiosis 78 (2): 115-123. DOI: 10.1007/s13199-01900602-w.

Ntalli NG, Caboni P. 2012. Botanical nematicides: a review. J Agric Food Chem 60 (40): 9929-9940. DOI: 10.1021/jf303107j.

O’Brien PA. 2017. Biological control of plant diseases. Australas Plant Path 46(4): 293-304. DOI: 10.1007/s13313-017-0481-4.

Pavithra G, Bindal S, Rana M, Srivastava S. 2020. Role of endophytic microbes against plant pathogens: a review. Asian J Plant Sci 19 (1): 54-62. DOI: 10.3923/ajps.2020.54.62.

Pieterse CM, Zamioudis C, Berendsen RL, Weller DM, Van Wees SC, Bakker PA. 2014. Induced systemic resistance by beneficia microbes. Annu Rev Phytopathol 52: 347-375. DOI 10.1146/annurev-phyto-082712-102340.

Podolich O, Ardanov P, Zaets I, Pirttilä AM, Kozyrovska N. 2015. Reviving of the endophytic bacterial community as a putative mechanism of plant resistance. Plant Soil 388 (1): 367-377. DOI: 10.1007/s11104-014-2235-1

Príncipe A, Alvarez F, Castro MG, Zachi L, Fischer SE, Mori GB, Jofré E. 2007. Biocontrol and PGPR feature in native strains isolated from saline soils of Argentina. Curr Microbiol 55 (4): 314-322. DOI: 10.1007/s00284-006-0654-9.

Ralmi NHAA, Khandaker MM, Mat N. 2016. Occurrence and control of root knot nematode in crops: a review. Aust J Crop Sci 11 (12): 16491654. DOI: $10.21475 /$ ajcs.2016.10.12.p7444.
Rosenblueth M, Martínez-Romero E. 2006. Bacterial endophytes and their interactions with hosts. Mol Plant Microbe Interact 19 (8): 827-837. DOI: 10.1094/MPMI-19-0827.

Santos MLd, Berlitz DL, Wiest SLF, Schünemann R, Knaak N, Fiuza LM. 2018. Benefits associated with the interaction of endophytic bacteria and plants. Braz Arch Biol Technol 61: e18160431. DOI: 10.1590/1678-4324-2018160431.

Shetty LJ, Sakr FM, Al-Obaidy K, Patel MJ, Shareef H. 2015. A brief review on medicinal plant Tagetes erecta Linn. J Appl Pharm Sci 5 (3): 91-95.

Singh T, Prajapati A, Maru A, Chaudhary R, Patel D. 2019. Root-knot nematodes (Meloidogyne spp.) infecting pomegranate: a review. Agric Rev 40 (4): 309-313. DOI: 10.18805/ag.R-1945.

Stoltzfus J, So R, Malarvithi P, Ladha J, De Bruijn F. 1997. Isolation of endophytic bacteria from rice and assessment of their potential for supplying rice with biologically fixed nitrogen. Plant Soil 194 (1): 2536. DOI: 10.1023/A:1004298921641.

Stroze CT, Baida FC, Balbi-Peña MI, Dias-Arieira CR, Santiago DC. 2019. Tagetes minuta propagation and interaction with Nematoide. J Agric Sci 11 (1): 139-148. DOI: 10.5539/jas.v11n1p139.

Sturz AV, Christie BR, Nowak J. 2000. Bacterial endophytes: potential role in developing sustainable systems of crop production. Crit Rev Plant Sci 19 (1): 1-30. DOI: 10.1080/07352680091139169.

Subedi S, Thapa B, Shrestha J. 2020. Root-knot nematode (Meloidogyne incognita) and its management: a review. J Agric Nat Resour 3 (2): 21-31. DOI: 10.3126/janr.v3i2.32298.

Taghavi S, Van Der Lelie D, Hoffman A, Zhang Y-B, Walla MD, Vangronsveld J, Newman L, Monchy S. 2010. Genome sequence of the plant growth-promoting endophytic bacterium Enterobacter sp. 638. PLoS Genet 6 (5): e1000943. DOI: 10.1371/journal.pgen.1000943.

Vallad GE, Goodman RM. 2004. Systemic acquired resistance and induced systemic resistance in conventional agriculture. Crop Sci 44 (6): 1920-1934. DOI: 10.2135/cropsci2004.1920.

Vallet-Gely I, Novikov A, Augusto L, Liehl P, Bolbach G, Péchy-Tarr M, Cosson P, Keel C, Caroff M, Lemaitre B. 2010. Association of hemolytic activity of Pseudomonas entomophila, a versatile soil bacterium, with cyclic lipopeptide production. Appl Environ Microbiol 76 (3): 910-921. DOI: 10.1128/AEM.02112-09.

Verma P, Verma A. 2012. Evaluation of antibacterial activity of different parts of Tagetes erecta. Int J Pharm Life Sci 3(6): 1766-1768.

Verma SC, Ladha JK, Tripathi AK. 2001. Evaluation of plant growthpromoting and colonization ability of endophytic diazotrophs from deepwater rice. J Biotechnol 91 (2-3): 127-141. DOI: 10.1016/S01681656(01)00333-9.

Win KT, Tanaka F, Okazaki K, Ohwaki Y. 2018. The ACC deaminase expressing endophyte Pseudomonas spp. enhances $\mathrm{NaCl}$ stress tolerance by reducing stress-related ethylene production, resulting in improved growth, photosynthetic performance, and ionic balance in tomato plants. Plant Physiol Biochem 127: 599-607. DOI: 10.1016/j.plaphy.2018.04.038.

Wiratno W, Syakir M, Sucipto I, Pradana AP. 2019. Isolation and characterization of endophytic bacteria from roots of Piper nigrum and their activities against Fusarium oxysporum and Meloidogyne $\begin{array}{llll}\text { incognita. } & \text { Biodiversitas } 20 \text { (3): 682-687. DOI: }\end{array}$ 10.13057/biodiv/d200310

Xu L-w, Juan C, QI H-y, SHI Y-p. 2012. Phytochemicals and their biological activities of plants in Tagetes L. Chin Herb Med 4 (2): 103117.

Yadav AN, Verma P, Singh B, Chauhan VS, Suman A, Saxena AK. 2017. Plant growth-promoting bacteria: biodiversity and multifunctional attributes for sustainable agriculture. Adv Biotechnol Microbiol 5 (5): 1-16. DOI: 10.19080/AIBM.2017.05.555671. 